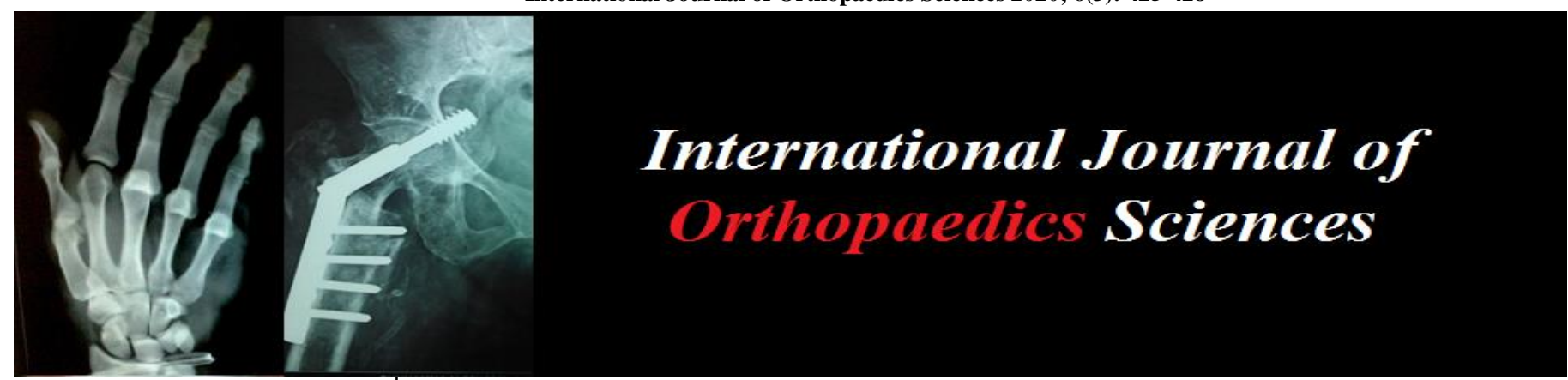

E-ISSN: 2395-1958

P-ISSN: 2706-6630

IJOS $2020 ; 6(3)$ : 425-428

(C) $2020 \mathrm{IJOS}$

www.orthopaper.com

Received: 16-05-2020

Accepted: 18-06-2020

Rajesh K Ambulgekar Professor \& HOD, Department of Orthopaedics, Dr. Shankarrao Chavan Government College and Hospital Nanded, Maharashtra, India

Siddharth M Katkade

$3^{\text {rd }}$ Year Resident, Department of Orthopaedics, Dr. Shankarrao Chavan Government College and Hospital Nanded, Maharashtra, India
Corresponding Author: Rajesh K Ambulgekar Professor \& HOD, Department of Orthopaedics, Dr. Shankarrao Chavan Government College and Hospital Nanded, Maharashtra, India

\section{Lumbar disc lesion: Study of epidemiology and surgical intervention}

\section{Rajesh K Ambulgekar and Siddharth M Katkade}

DOI: https://doi.org/10.22271/ortho.2020.v6.i3g.2233

\section{Abstract}

Background: As per European studies the incidence of a herniated disc is about 5 to 20 cases per 1000 adults annually and is most common in people in their third to the fifth decade of life, with a male to female ratio of $2: 1$. The estimated prevalence of symptomatic herniated disc of the lumbar spine is about 1-3 percent of patients. Epidemiology of lumbar disc disease among Indian population needing operative intervention is not clear.

Aim: To study the Epidemiology of lumbar disc disease among Indian population needing operative intervention.

Material and Methods: In this prospective study all the adult (above 18 years) age group presenting with lumbar disc lesion and canal stenosis admitted in orthopaedic department of Tertiary Care Centre satisfying inclusion were taken for study after obtaining their consent.

Results: Out of 120 patients $25 \%$ patients needed and rest were managed by conservative line of management. The more common age group affected was 40 to 60 years age group $(53.33 \%)$. Gender distribution has a male predominance $(73.33 \%)$ compare to females $(26.66 \%)$. Majority of the cases studied were presented with low backache, radiculopathy and paraesthesia. Majority having L4-L5 disc involvement $(70 \%)$.

Conclusion: Out of 120 patients $30(25 \%)$ patients needed operative intervention and rest were managed by conservative line of management. All patients with lumbar disc lesion needs conservative trial. Only if conservative trial fails or patient with persistent disabilating pain or neurological deficit are subjected to operative intervention. Majorly affect 40 to 60 years age group with mean of 44.9 years \& males outnumbering females in incidence with majority involving L4-L5 disc level.

Keywords: Lumbar disc lesion, adults, minimal invasive lumbar discectomy, epidemiology

\section{Introduction}

Humans are the sufferers of back and leg and pain since the history. The ancient cures, of back pain is now appearing as a modern international epidemic. In entire lifespan upto $80 \%$ of people are affected by this symptom at some time. The most frequent cause of limitation of activity in people younger than +5 years is impairments of the back and spine as by the national center for health statistics. In otherwise healthy people in the 3rd and 4th decades of life intervertebral disc disease and disc herniation are most prominent. It accounts for a majority of cases of low backache in clinical practice and also a major contributor of limitation in day to day activities.

In 1934, Mixter and Barr published their study that concluded that the suffering caused by sciatic pain can be improved by laminectomy with decompression and extraction of herniated lumbar disc ${ }^{[27]}$. Since then increasing number of patients have been operated upon for this disorder. "Gold standard" for operative intervention in patients with herniated lumbar discs whose conservative treatment has failed is now the Open discectomy.

Discectomy first reported by Mixter and Barr ${ }^{[1]}$ (1934) has changed the management of lumbar disc herniations. Kambin and Savitz ${ }^{[2]}$ (1973) introduced the concept of endoscopic lumbar discectomy. Caspar ${ }^{[3]}$ (1977), Yasargil ${ }^{[4]}$ (1977) and Williams ${ }^{[5]}$ (1978) added refinements in approach with the use of microsurgical technique. Foley and Smith ${ }^{[6]}$ (1997) introduced an operative endoscope with the tubular system terming it "Endoscopic Discectomy". As an alternative to the endoscope, Foley et al. (2003) modified the tubular retractors to include a microscope, which is termed "Micro Endoscopic Discectomy" (MED). 
The term is used interchangeably for describing the discectomy procedure utilizing tubular retractors either with an endoscope or a microscope [7]. Recent prospective randomized control trials (RCTs) have found a benefit of surgery for patients when conservative therapies fail. [8${ }^{11]}$ Discectomy performed open or with an operating microscope remains the standard surgical management [12${ }^{14]}$ Tubular retractor system ${ }^{[15-17]}$ is being increasingly used now. The potential benefits of to this technique include less muscle and local damage, better cosmesis ${ }^{[18-20]}$ decreased pain and operative time and faster recovery after surgery [21, ${ }^{22]}$ On the other hand, open surgery includes extensive retraction and dissection of paraspinal muscles, longer operative time, longer incisions and bone resection ${ }^{23,24]}$

However, the outcome studies of lumbar disc surgery document a success rate of 51 to $89 \%$ in spite of advances in investigations, operative technique is important.

Hence, plotting epidemiology of lumbar disc disease patients needing operative intervention will give us a guide for patient selection and plan the management.

\section{Material and Methods}

In this prospective study 120 patients with lumbar disc disease were screened using the inclusion and exclusion criteria. Informed consent was taken for all patients and approval of the Institutional Review Board was obtained prior to the commencement of the study.

\section{Inclusion criteria}

1. All lumbar disc lesion and spinal stenosis patients

2. Medically fit for surgery

3. Patients with age $>18$ years

\section{Exclusion criteria}

1. Lumbar disc lesion and spinal stenosis managed nonoperatively

2. Medical contraindication for surgery

3. Patient with age $<18$ years
A detailed history was obtained and they were subjected to a thorough clinical examination. Radiological investigations (plain x-ray and MRI lumbar spine) were carried out to confirm the diagnosis and know the level of the lesion. The patients were also assessed pre-operatively with the Owestry low back pain disability score. All 120 patients were managed conservatively with bed rest, pelvic traction and analgesics among these 30 patients who had already taken conservative management for more than 6-8 months with unresolving symptoms or patients with disabilating pain or neurological deficit where subjected to operative intervention taken into study. All patients underwent minimal invasive discectomy surgery in the prone position. Postoperatively the patients were followed up after $1_{\mathrm{st}}, 2_{\mathrm{nd}}, 3_{\mathrm{rd}}, 6_{\text {th }}$ months and thereafter yearly. The Owestry low back pain disability score used postoperatively to assess the outcome analysis of functional status.

\section{Results}

A hospital based prospective study was done with 30 patients with lumbar disc lesion and spinal stenosis in adults treated with image guided minimal invasive technique.

Table 1: Patient characteristics

\begin{tabular}{|c|c|c|}
\hline Characteristics & No. of patients & Percentage (\%) \\
\hline Age group (years) & & \\
\hline $20-40$ & 10 & $33.4 \%$ \\
\hline $40-60$ & 16 & $53.3 \%$ \\
\hline$\geq 60$ & 4 & $13.4 \%$ \\
\hline Sex & & \\
\hline Male & 22 & $73.33 \%$ \\
\hline Female & 8 & $26.66 \%$ \\
\hline
\end{tabular}

Majority of cases i.e. $16(53.3 \%)$ were in the age group of 40 60 years. The minimum age of the patient was 28 years and maximum was 66 years. The more common age group affected was 40 to 60 years age group with the average of 44.9 years with significant male predominance.

Table 2: Distribution of disc level involved

\begin{tabular}{|c|c|c|}
\hline Level & No. of patients & Percentage (\%) \\
\hline L4-L5 & 21 & 70 \\
\hline L5-S1 & 4 & 13 \\
\hline L3-L4 \& L4-L5 & 2 & 6 \\
\hline L4-L5 \& L5-S1 & 3 & 10 \\
\hline Total & 30 & 100.0 \\
\hline
\end{tabular}

Majority of the patients had L4-L5 disc involvement i.e. 21 (70\%) compare to L5-S1 disc involvement which was $13 \%$, combination of L4-L5 \& L5-S1- 10\% and L3-L4 \& L4-L5 $6 \%$. It shows L4-L5 disc involvement significant predominance compare to others.

Table 2: Distribution according to presenting symptoms

\begin{tabular}{|c|c|c|}
\hline Symptoms & No. of patients & Percentage (\%) \\
\hline Low backache & 27 & 90 \\
\hline Radicular pain & 30 & 100 \\
\hline Paraesthesia & 23 & 76.6 \\
Weakness & 7 & 23.3 \\
\hline Bowel/Bladder symptoms & 0 & 0 \\
\hline
\end{tabular}

Majority of the cases studied were presented with low backache, radiculopathy and paraesthesia of which majority having L4-L5 disc involvement.

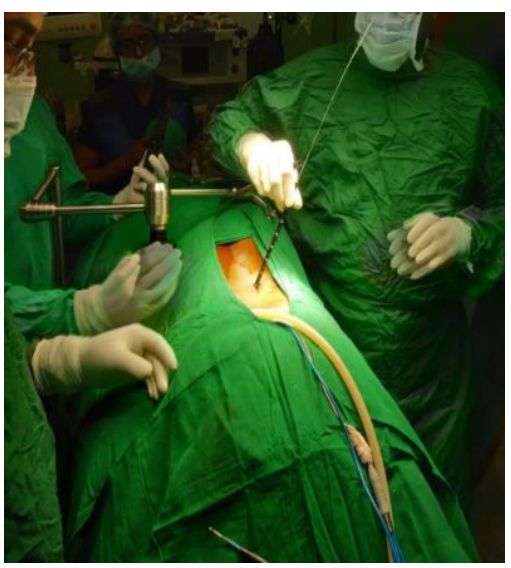

Guide wire localization and serial dilator insertion 


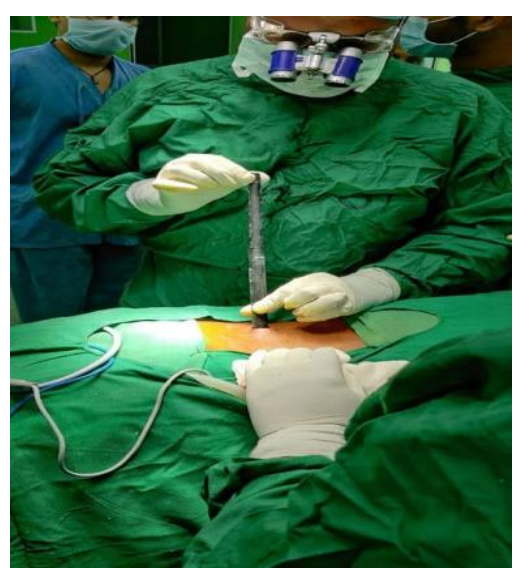

Serial tubular rector insertion

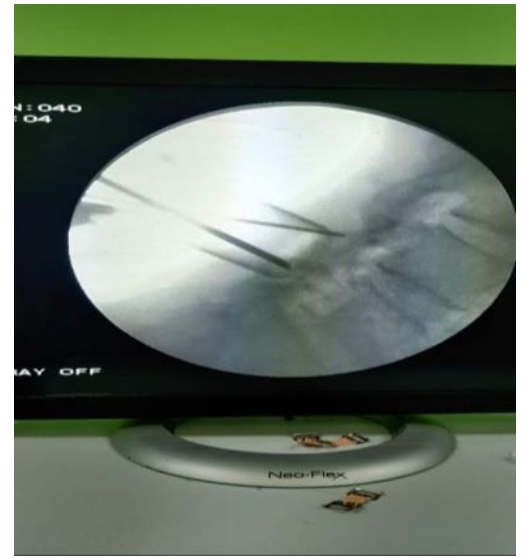

Radiographic confirmation

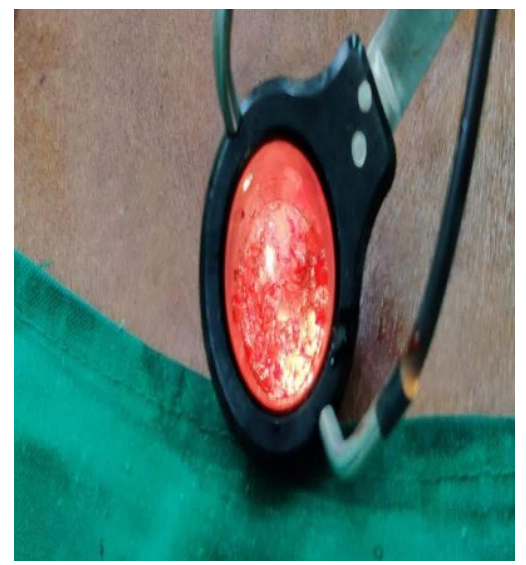

Operating field view illuminated with fibre optic

\section{Discussion}

In our study we used Owestry disability scoring system for functional outcome. At the end of mean follow up of 8.5 months (ranging from 6 to 12 months) as per Owestry disability scoring system outcome was plotted into good, fair and poor. We found good result in 15 patients $(50 \%)$, fair result in 10 patients $(33.33 \%)$ and poor result in 5 patients $(16.66 \%)$. Using Owestry disability scoring system we had more than $80 \%$ good to fair outcome. Since we could achieve good spinal decompression with minimal blood loss and soft tissue damage leading to early rehabilitation and minimal post operative hospital stay indicates overall good outcome and promotes minimal invasive lumbar discectomy over open technique.

All 120 patients were managed conservatively with bed rest, pelvic traction and analgesics among these 30 patients who had already taken conservative management for more than 6-8 months with unresolving symptoms or patients with disabilating pain or neurological deficit where subjected to operative intervention taken into study. All patients underwent minimal invasive lumbar discectomy with tubular retractor system.

All 120 patients were managed conservatively with bed rest, pelvic traction and analgesics among these 30 patients who had already taken conservative management for more than 6-8 months with unresolving symptoms or patients with disabilating pain or neurological deficit where subjected to operative intervention taken into study. All patients underwent minimal invasive discectomy surgery in the prone position. Postoperatively the patients were followed up after $1_{\text {st }}, 2_{\text {nd }}, 3_{\text {rd }}, 6_{\text {th }}$ months and thereafter yearly. The Owestry low back pain disability score used post-operatively to assess the outcome analysis of functional status.

Postoperatively the patients were followed up after $1_{\mathrm{st}}, 2_{\text {nd }}$, $3_{\text {rd }}, 6$ th months and thereafter yearly. The Owestry low back pain disability score used post-operatively to assess the outcome analysis of functional status.

\section{Conclusion}

Out of 120 patients $30(25 \%)$ patients needed operative intervention and rest were managed by conservative line of management. All patients with lumbar disc lesion needs conservative trial. Only if conservative trial fails or patient with persistent disabilating pain or neurological deficit are subjected to operative intervention. Majorly affect 40 to 60 years age group with mean of 44.9 years \& males outnumbering females in incidence with majority involving L4-L5 disc level.

\section{Referrence}

1. Mixter WJ, Barr JS. Rupture of the intervertebral disc with involvement of the spinal canal. $\mathrm{N}$ Engl $\mathrm{J}$ Med. 1934; 211:210-5. [Google Scholar]

2. Kambin P, Savitz MH. Arthroscopic microdiscectomy: An alternative to open disc surgery. Mt Sinai J Med. 2000; 67:283-7. [PubMed] [Google Scholar]

3. Caspar W. A new surgical procedure for lumbar disc herniation causing less tissue damage through a microsurgical approach. In: Wullenweber R, Brock M, Hamer J, editors. Advances in Neurosurgery. Berlin: Springer-Verlag, 1977, 74-7. [Google Scholar]

4. Yasargil MG. Microsurgical operation for herniated disc. In: Wullenweber R, Brock M, Hamer J, Klinger M, Spoerri O, editors. Advances in Neurosurgery. Berlin: Springer-Verlag; 1977, 81. [Google Scholar]

5. Williams RW. Microlumbar discectomy: A conservative surgical approach to the virgin herniated lumbar disc. Spine (Phila Pa 1976). 1978; 3:17582. [PubMed] [Google Scholar]

6. Foley KT, Smith MM. Microendoscopic discectomy. Techniques in Neurosurgery. 1997; 3:301-7. [Google Scholar]

7. Kulkarni AG, Dhruv AN, Bassi AJ. Microendoscopic Excision of C2 osteoid osteoma: A Technical Report. Spine (Phila Pa 1976). 2008; 38:E1231-4. [PubMed] [Google Scholar]

8. Atlas SJ, Keller RB, Wu YA, Deyo RA, Singer DE. Longterm outcomes of surgical and nonsurgical management of sciatica secondary to a lumbar disc herniation: 10 year results from the Maine lumbar spine study. Spine (Phila Pa 1976). 2005; 30:927-35. 
[PubMed] [Google Scholar]

9. Pearson AM, Blood EA, Frymoyer JW, Herkowitz H, Abdu WA, Woodward $\mathrm{R}$ et al. SPORT lumbar intervertebral disk herniation and back pain: Does treatment, location, or morphology matter? Spine (Phila $\mathrm{Pa}$ 1976). 2008; 33:428-35. [PMC free article] [PubMed] [Google Scholar]

10. Peul WC, van Houwelingen $\mathrm{HC}$, van den Hout WB, Brand R, Eekhof JA, Tans JT et al. Surgery versus prolonged conservative treatment for sciatica. $\mathrm{N}$ Engl $\mathbf{J}$ Med. 2007; 356:2245-56. [PubMed] [Google Scholar]

11. Gibson JN, Waddell G. Surgical interventions for lumbar disc prolapse: Updated Cochrane Review. Spine (PhilaPa 1976). 2007; 32:1735-47. [PubMed] [Google Scholar]

12. Tait MJ, Levy J, Nowell M, Pocock C, Petrik V, Bell BA et al. Improved outcome after lumbar microdiscectomy in patients shown their excised disc fragments: A prospective, double blind, randomised, controlled trial. J Neurol Neurosurg Psychiatry. 2009; 80:10446. [PubMed] [Google Scholar]

13. Katayama Y, Matsuyama Y, Yoshihara H, Sakai Y, Nakamura H, Nakashima S et al. Comparison of surgical outcomes between macro discectomy and micro discectomy for lumbar disc herniation: A prospective randomized study with surgery performed by the same spine surgeon. J Spinal Disord Tech. 2006; 19:3447. [PubMed] [Google Scholar]

14. McGirt MJ, Ambrossi GL, Datoo G, Sciubba DM, Witham TF, Wolinsky JP et al. Recurrent disc herniation and long term back pain after primary lumbar discectomy: Review of outcomes reported for limited versus aggressive disc removal. Neurosurgery. 2009; 64:338-45. [PubMed] [Google Scholar]

15. Freudenstein D, Duffner F, Bauer T. Novel retractor for endoscopic and microsurgical spinal interventions. Minim Invasive Neurosurg. 2004; 47:190-5. [PubMed] [Google Scholar]

16. Husain M, Jha DK, Agrawal S, Husain N, Gupta RK. Conical working tube: A special device for endoscopic surgery of herniated lumbar discs. J Neurosurg Spine. 2005; 2:265-70. [PubMed] [Google Scholar]

17. Isaacs RE, Podichetty V, Fessler RG. Microendoscopic discectomy for recurrent disc herniations. Neurosurg Focus. 2003; 15:E11. [PubMed] [Google Scholar]

18. Schick U, Döhnert J, Richter A, König A, Vitzthum HE. Microendoscopic lumbar discectomy versus open surgery: An intraoperative EMG study. Eur Spine J. 2002; 11:20-6. [PMC free article] [PubMed] [Google Scholar]

19. Shin DA, Kim KN, Shin HC, Yoon H. The efficacy of Microendoscopic discectomy in reducing iatrogenic muscle injury. J Neurosurg Spine. 2008; 8:39-43. [PubMed] [Google Scholar]

20. Kotil K, Tunckale T, Tatar Z, Koldas M, Kural A, Bilge T. Serum creatine phosphokinase activity and histological changes in the multifidus muscle: A prospective randomized controlled comparative study of discectomy with or without retraction. J Neurosurg Spine. 2007; 6:121-5. [PubMed] [Google Scholar]

21. Harrington JF, French P. Open versus minimally invasive lumbar microdiscectomy: Comparison of operative times, length of hospital stay, narcotic use and complications. Minim Invasive Neurosurg. 2008; 51:305. [PubMed] [Google Scholar]

22. Yeung AT, Yeung CA. Minimally invasive techniques for the management of lumbar disc herniation. Orthop Clin North Am. 2007; 38:363-72. [PubMed] [Google Scholar]

23. Mayer HM, Brock M. Percutaneous endoscopic discectomy: Surgical technique and preliminary results compared to microsurgical discectomy. J Neurosurg. 1993; 78:216-25. [PubMed] [Google Scholar]

24. Ditsworth DA. Endoscopic transforaminal lumbar discectomy and reconfiguration: A postero-lateral approach into the spinal canal. Surg Neurol. 1998; 49:588-98. [PubMed] [Google Scholar] 